\title{
Historical and Archaeological Research of the Hampton Inn Property in Downtown San Antonio
}

Marcie Renner

Center for Archaeological Research

Follow this and additional works at: https://scholarworks.sfasu.edu/ita

Part of the American Material Culture Commons, Archaeological Anthropology Commons, Environmental Studies Commons, Other American Studies Commons, Other Arts and Humanities Commons, Other History of Art, Architecture, and Archaeology Commons, and the United States History Commons

Tell us how this article helped you.

This Article is brought to you for free and open access by the Center for Regional Heritage Research at SFA ScholarWorks. It has been accepted for inclusion in Index of Texas Archaeology: Open Access Gray Literature from the Lone Star State by an authorized editor of SFA ScholarWorks. For more information, please contact cdsscholarworks@sfasu.edu. 


\section{Historical and Archaeological Research of the Hampton Inn Property in}

Downtown San Antonio

\section{Creative Commons License}

\section{(c) (1) \&}

This work is licensed under a Creative Commons Attribution-NonCommercial 4.0 International License 


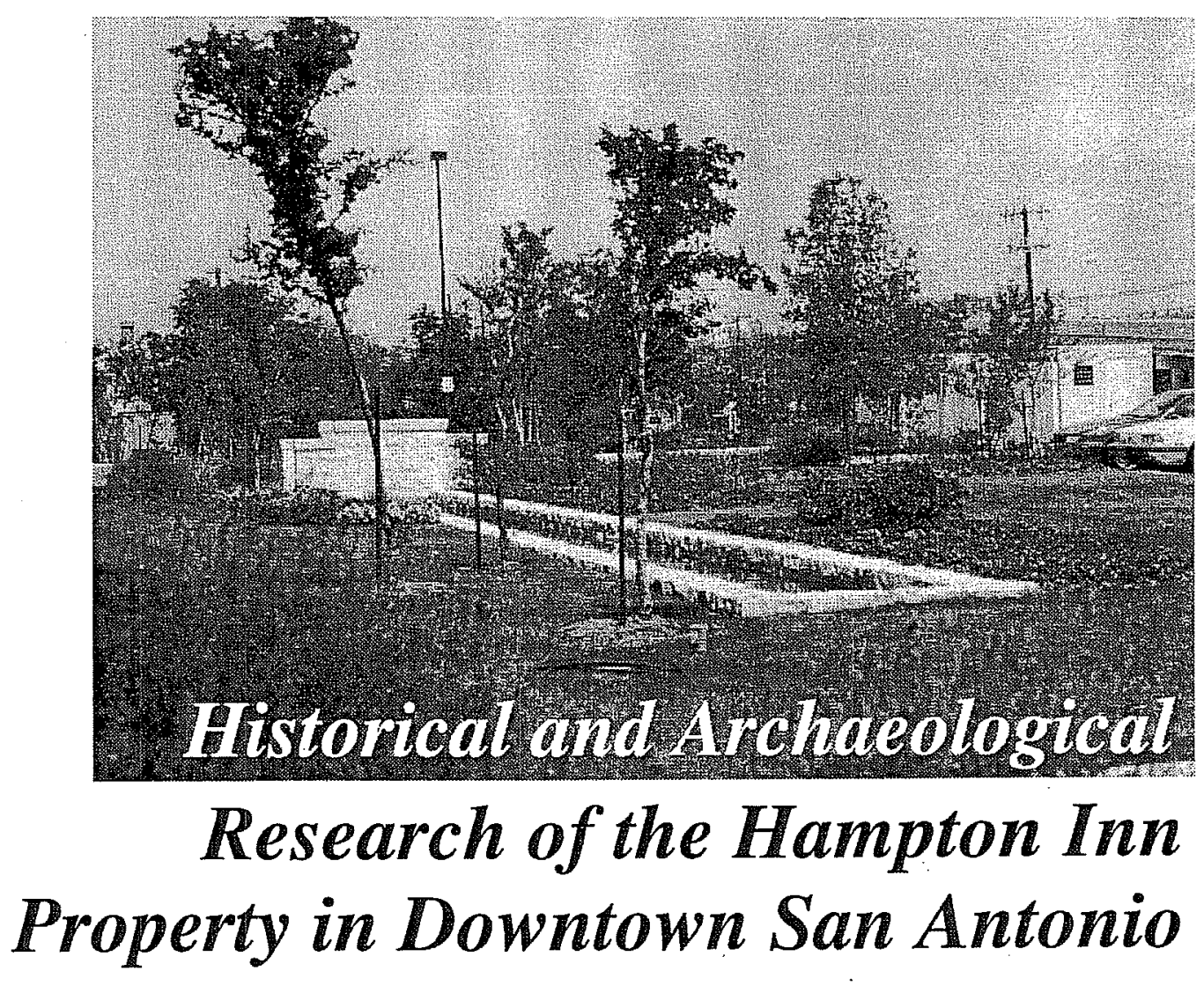

\section{edited by Marcie Renner}

with contributions by Anne A. Fox,

I. Waynne Cox, and Herbert G. Uecker

Archaeological Survey Report, No. 246

Center for Archaeological Research

The University of Texas at San Antonio 



\section{Historical and Archaeological Research of the Hampton Inn Property in Downtown San Antonio}

edited by Marcie Renner

with contributions by Anne A. Fox,

I. Waynne Cox, and Herbert G. Uecker

Robert J. Hard, Jack D. Eaton, and C. Britt Bousman Principal Investigators

${ }^{\circ}$ copyright

Archaeological Survey Report, No. 246

Center for Archaeological Research

The University of Texas at San Antonio

1997 
The following information is provided in accordance with the General Rules of Practice and Procedure, Chapter 41.11 (Investigative Reports), Texas Antiquities Committee:

1. Type of investigation: Archival research and monitoring

2. Project name: Hampton Inn

3. County: Bexar

4. Principal investigators: Robert J. Hard, Jack D. Eaton, and C. Britt Bousman

5. Name and location of sponsoring agency: Hampton Inns, Inc., 6799 Great Oaks Road, Suite 100, Memphis, Tennessee 38138-2571

6. Texas Antiquities Committee Permit No.: n/a

7. Published by the Center for Archaeological Research, The University of Texas at San Antonio, San Antonio, Texas 78249-0658, 1997

A list of publications offered by the Center for Archaeological Research is available. Call (210) 458-4378; write to the Center for Archaeological Research, The University of Texas at San Antonio, 6900 N. Loop 1604 W., San Antonio, Texas 78249-0658; e-mail to car@lonestar.utsa.edu; or visit CAR's Web site at http://www.csbs.utsa.edu/research/car/index.htm. 


\section{Abstract}

The Center for Archaeological Research of The University of Texas at San Antonio conducted a three-phase investigation of property belonging to Hampton Inns, Inc., in downtown San Antonio, Texas. The first phase, a study of archival records and previous investigations, undertaken in 1989, showed that portions of the Alamo Acequia Madre ran through the property. During Phase II, in 1990, CAR placed five backhoe trenches to assess the remains of the acequia. These investigations showed the acequia to have been disturbed by earlier installation of a storm drain. CAR archaeologists monitored construction activities during Phase III in early 1995. Although small portions of two structures were revealed, no associated artifacts were found. Sixteen artifacts dating from the late-nineteenth- to early twentieth-centuries were recovered near the acequia. These probably represent a trash deposit of some kind. A portion of the acequia has been reconstructed in the courtyard, and the recovered artifacts are on display in the hotel. 


\section{Contents}

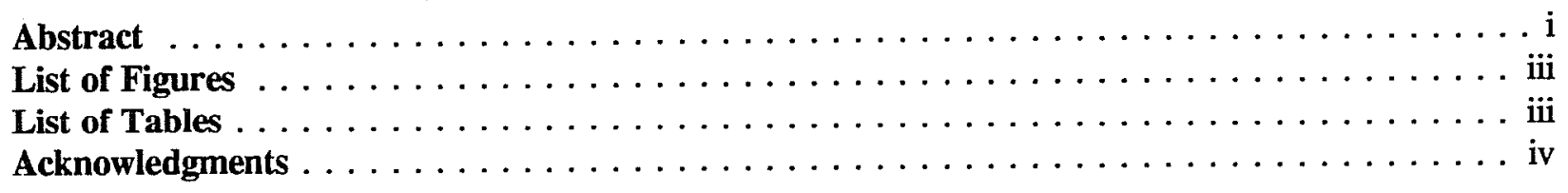

Introduction $\ldots \ldots \ldots \ldots \ldots \ldots \ldots \ldots \ldots \ldots \ldots \ldots \ldots \ldots \ldots \ldots \ldots \ldots$

Part 1. Archival and Historical Research

Anne A. Fox and Herbert G. Uecker . . . . . . . . . . . . . . . . . . . 2

Part 2. Backhoe Testing and Documentation of the Alamo Acequia

Anne A. Fox . . . . . . . . . . . . . . . . . . . . . . . . . . . 12

Part 3. Final Monitoring During Construction

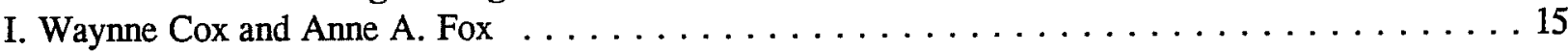

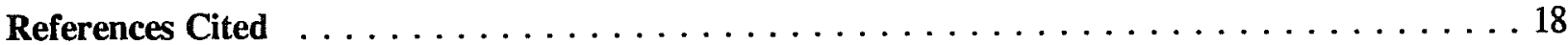




\section{Figures}

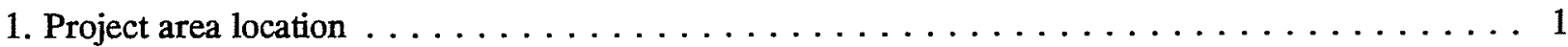

2. Maximum residential development on the Hampton Inn site $\ldots \ldots \ldots \ldots \ldots \ldots \ldots \ldots$

3. "Adobe" houses facing onto Bowie Street, ca. $1920 \ldots \ldots \ldots \ldots \ldots \ldots \ldots \ldots \ldots$

4. Detail of Augustus Koch's 1873 Bird's Eye View of the City of San Antonio . . . . . . . . . . . 6

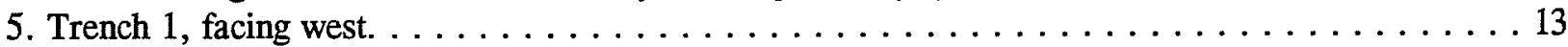

6. Trench 4, from above, showing the east wall of the acequia and the covered drain $\ldots \ldots \ldots \ldots 14$

7. Reconstructed acequia in the courtyard of the Hampton Inn, $1996 \ldots \ldots \ldots \ldots \ldots \ldots \ldots$

8. Reconstructed acequia in the courtyard of the Hampton Inn, $1996 \ldots \ldots \ldots \ldots \ldots \ldots \ldots$

\section{Tables}

1. Residents on The Hampton Inn Property in $1905 \ldots \ldots \ldots \ldots \ldots \ldots \ldots \ldots$. . . . 8

2. Residents on The Hampton Inn Property in $1910 \ldots \ldots \ldots \ldots \ldots \ldots \ldots \ldots \ldots \ldots \ldots \ldots \ldots \ldots$

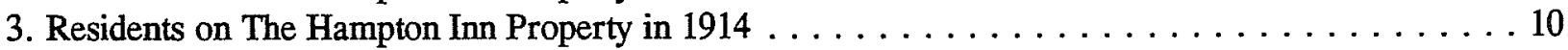

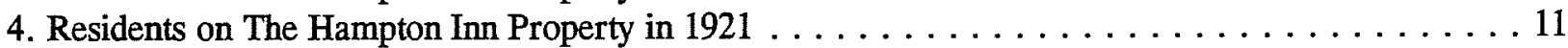

5. Elevation of Selected Points in Acequia Backhoe Trenches $\ldots \ldots \ldots \ldots \ldots \ldots \ldots \ldots \ldots \ldots$

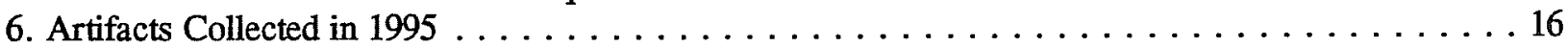




\section{Acknowledgments}

We would like to acknowledge the help of a number of people who have facilitated the accomplishment of this project over the years. For recognizing the importance of the acequia going through the property and consulting the Center for Archaeological Research (CAR) on how to protect it, we owe thanks to Michael Goforth, senior project manager for Hampton Inns, Inc. The result of his interest and persistence has been this record of a small portion of the history of downtown San Antonio which would otherwise have vanished into obscurity.

Thanks also go to Wrightway Backhoe for careful trench excavations and to Tommy Tomesal for volunteering his time during the trenching work. Clint McKenzie of the San Antonio Historic Preservation Office helped by regularly monitoring the progress of the construction. CAR staff members Barbara Meissner and Bruce Moses are to be thanked for their help with the final monitoring and the illustration drafting, respectively. Our appreciation also to Harry Moeller and Bill Johnson of Browning Construction Company for their aid in accomplishing the final stage of the work. 


\section{Introduction}

Incorporated into this publication are three individual reports produced over the past seven years in connection with the construction of a Hampton Inn in downtown San Antonio. The impetus for historical and archaeological investigations began with Michael Goforth, senior project manager for Hampton Inns, Inc. Goforth recognized the historical importance of the acequia on their property-while the project was still in the planning stage-and contacted the Center for Archaeological Research (CAR) of The University of Texas at San Antonio for help and advice on what would need to be done to protect it. The resulting reconstructed acequia section behind the hotel demonstrates the concern of the company for the history of the area.
The project area encompasses a group of lots in New City Blocks 555 and 554, in an area generally bounded by Bowie, Nacogdoches, Elm, and Houston streets (Figure 1). Part I of this report traces the history of the development of this small section of San Antonio from Colonial times, when the property belonged to the Spanish government, to the present. The results of the historical and archival research prompted Hampton Inns to conduct archaeological testing prior to development of the property, and monitoring during construction of the hotel. The results of the testing and monitoring phases are presented in Parts II and III of this report, respectively.

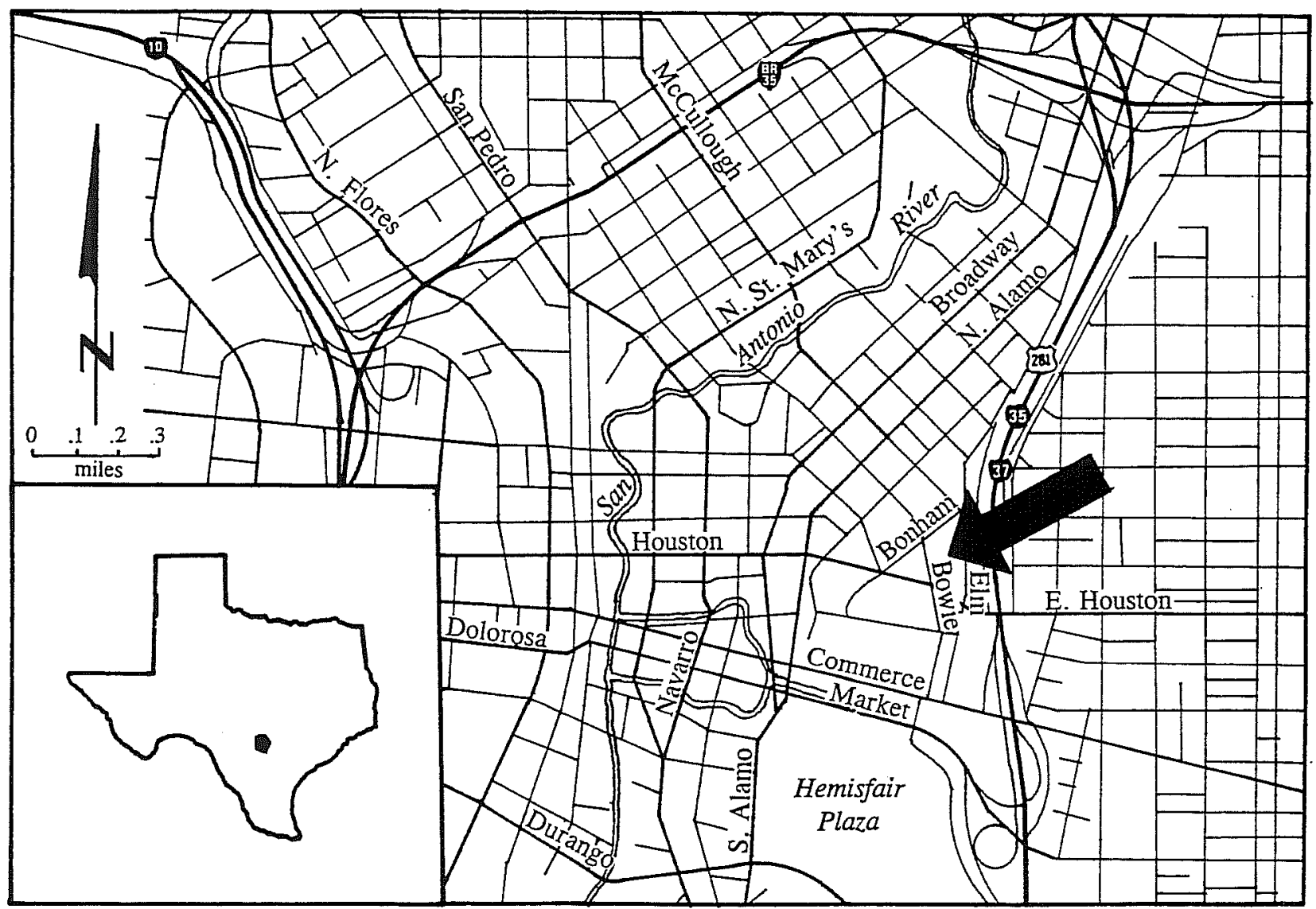

Figure 1. Project area location. 


\section{Part 1. Archival and Historical Research}

\section{Anne A. Fox and Herbert G. Uecker}

\section{Introduction}

The first phase of the Hampton Inn project, conducted in 1989, involved archival and historical research to trace the history of the development of the project area from Colonial times, when the property belonged to the Spanish government, to the present. Principal investigator for Phase I was Jack D. Eaton. Anne A. Fox served as co-principal investigator and project director, and was assisted by Herbert G. Uecker.

\section{General History of the Area}

In recent decades our knowledge of the details of the history of the city of San Antonio has grown impressively. To a significant degree, this has been due to an increasing number of archaeological and archival investigations regarding properties in or near modern downtown commercial and residential districts (Fox 1977; Fox et al. 1977; Fox et al. 1978; Fox et al. 1987; Fox and Ivey 1979; Katz 1978; Labadie 1987). In turn, these investigations have resulted mostly from interaction between municipal authorities, private developers, and the archaeological community.

From research for an archaeological project on Houston Street just east of the Alamo, McGraw (1987) suggests seven chronological periods into which the general history of this section of San Antonio may be divided:

1. historic Indian and Spanish colonial period

2. secularization and early Mexican

3. Texas Republic and annexation

4. mid-late nineteenth century (from early statehood to Civil War)
5. reconstruction

6. late-nineteenth-and early twentieth-century residential

7. twentieth-century commercial.

This breakdown illustrates the potential complexity of historic archaeological sequences in the area. For purposes of this report, a somewhat simpler analysis based mostly on land usages is more appropriate:

1. Spanish colonial mission expansion

2. Spanish land grant

3. land speculation and development

4. late-nineteenth- and twentieth-century residential and commercial.

A brief presentation of the history of the San Antonio Hampton Inn site based on these periods follows.

\section{Mission Expansion Period}

The Spanish colonial period of the history of San Antonio began in the early 1700 s during an acceleration of Spain's expansion in the New World. Spain first claimed the land which later became Texas in the middle 1600 s. The French began to try to infiltrate this territory only a few decades later with the LaSalle expedition, which left France in 1684 and landed later that year on Matagorda Island (Fox 1983). The LaSalle venture was poorly undertaken and posed little threat to the Spanish. Within only a few years it failed miserably when most of the colonists died of disease or at the hands of hostile Indians. The few who survived left the area, never to return. The ill-fated colony, however, had alerted the Spanish, 
who immediately set about intensifying their hold on Texas.

The Spanish Catholic missions were soon extended as far north as the present site of the city of San Antonio. Here, the Mission San Antonio de Valero, now commonly known as the Alamo, was built near the headwaters of San Pedro Creek in 1718 (Habig 1968:38). By the time of its establishment, the Spaniards had fairly well systematized their expansion efforts. They would usually locate their missions near a permanent source of good quality water, then construct acequias (irrigation ditches) to water adjacent fields and orchards. One branch of the Mission Valero acequia passes through the Hampton Inn proposed construction site (Figure 2).

The Spaniards effectively converted the nearby populations of Indians. Once part of the mission community, the native peoples were used as a source of inexpensive labor for domestic and agricultural purposes. Within about the next half century, much of the aboriginal population in the area died off from exposure to European diseases combined with the other stresses of the sudden imposition of the foreign regime. Nevertheless, the Spanish presence continued to be adequately supported in Texas-employing Indian labor-until about the 1780 s.

\section{Spanish Land Grant Period}

Political and economic pressures brought about the secularization of the missions near the end of the eighteenth century. Soon after secularization, the crown began to parcel out property near the missions for settlement via land grants made directly to citizens. Several such grants specifically relate to the San Antonio Hampton Inn site:

1. Tract No. 26, described as one suerte of land sufficient to plant six pecks of corn, was granted to José de Sepeda on February 25, 1793 (Spanish Deed Records [SDR], Office of the County Clerk, Bexar County Courthouse, San Antonio, Texas; 3:302)
2. Tract No. 27, also described as one suerte of land sufficient to plant six pecks of corn, was granted to Manuel de la Cruz on the same date (SDR, 3:302)

3. A tract of land described as being one suerte with corresponding water, close to the gate of the labores of the barrio de Valero, having 100 varas front by a depth of 240 varas, bounded on the north by the water outlet, on the south by the property of the widow of Juan Bautista de la Cerda, on the west by Charle's property, and on the east by the Acequia Madre, was granted to Diego Perez on February 22, 1818 (Bexar County Deed Records [BCDR], Office of the County Clerk, Bexar County Courthouse, San Antonio, Texas; J1:232).

\section{Land Speculation and Development Period}

Many of these grants were apparently used almost continually for agricultural purposes until about the mid-nineteenth century, when they were sold to land speculators, investors, and developers. In about 1849 the present-day San Antonio Hampton Inn site, along with a large quantity of surrounding land, was purchased by J. J. Giddings, a developer who later became mayor of San Antonio. Giddings partitioned the land as Alamo City Subdivision, out of which he sold numerous tracts during the next decade.

Most of the lots within the hotel site were sold to at least one intervening speculator before they were acquired by a landowner who built a home on the lot (BCDR H1:367, I2:552, I2:526, J2:11). These transactions often occurred in rather quick succession and, by 1853 , most of the lots contained small "adobe" houses (Figure 3). As used in early San Antonio, the term refers to a soft, easily cut limestone which-like adobe-required plastering. Many of the families that established their homesteads in this period continued to own their lots for several generations. 


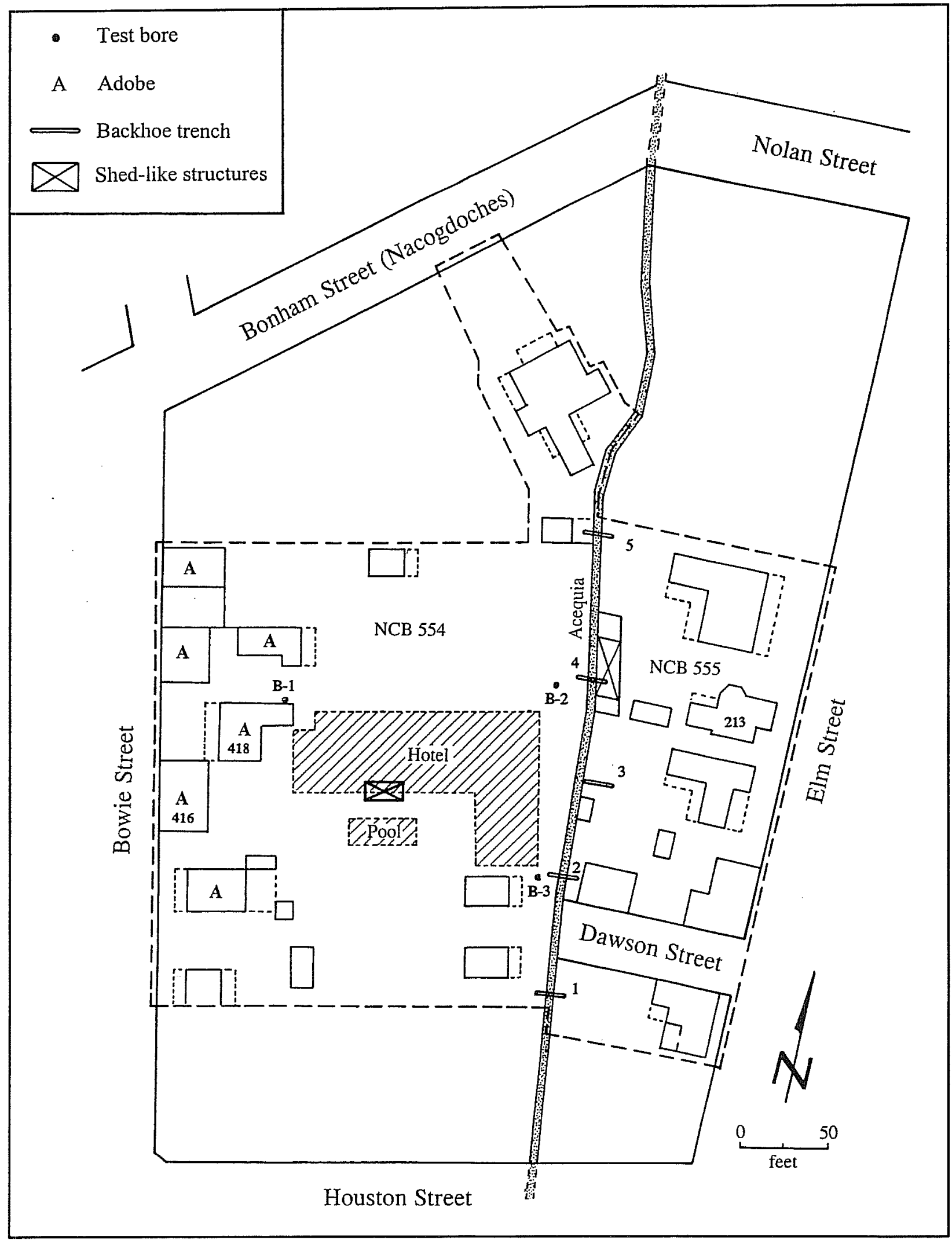

Figure 2. Maximum residential development on the Hampton Inn site. Adapted from the 1896 Sanborn Map. Shaded area is proposed hotel location. 


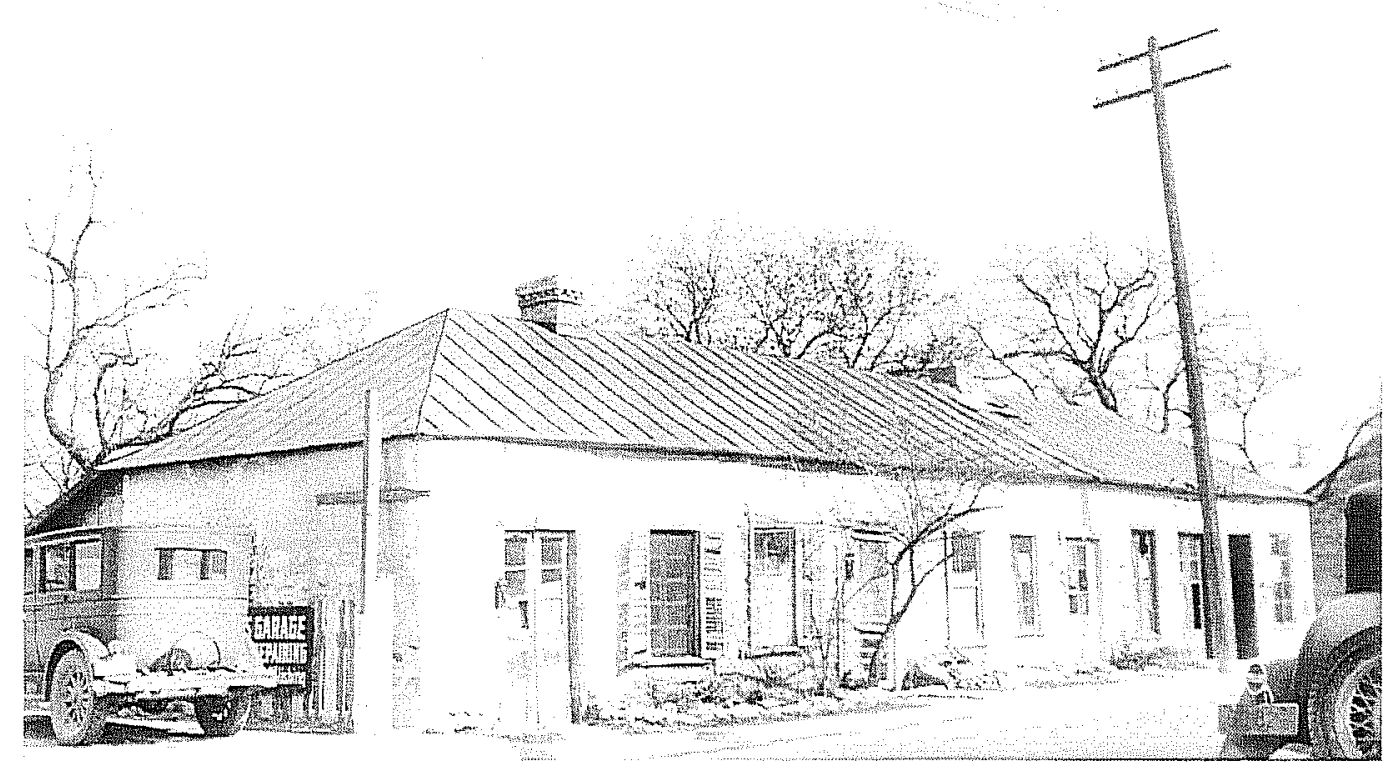

Figure 3. "Adobe" houses facing onto Bowie Street, ca. 1920. Daughters of the Republic of Texas Library.

Augustus Koch's 1873 Bird's Eye View of the City of San Antonio (map on file at the Daughters of the Republic Library, The Alamo, San Antonio, Texas) shows all the small adobes in place lining Bowie, Nacogdoches, and Elm streets, with the waters of the acequia running in a stone-lined ditch through their backyards (Figure 4). A small neighborhood grocery store was located at the corner of Bowie and Nacogdoches streets, just outside the boundaries of the hotel site (City Directory [CD] 1877:92).

The first homeowners in the neighborhood were predominantly German immigrants, who were arriving in great numbers in this part of Texas during the 1840 s and 1850 s. For example, Henry Lohrberg, a sausage maker, had his home and shop on Bowie Street (CD 1877:137). To the north on the same street lived Mrs. Frances Seng, a widow who was raising several children by herself (CD 1877:175). In 1883 Mrs. Seng's sons Edward and William, respectively bookkeeper and delivery clerk for the Nic Teng bookstore (CD 1883:279), were still living at home with their mother. Across the acequia in a house facing onto Elm Street were Christloeb Mueller and his family. Mueller also had a small grocery store in the neighborhood (CD 1877:150).

\section{Late-Nineteenth- and Twentieth-Century Residential and Commercial Period}

By 1887 Jacob Vollmar had a blacksmith shop at his home on Bowie Street (CD 1887:377). The only other major change in the neighborhood before 1900 was the opening of an extension of Dawson Street to allow access to two small frame houses just across the acequia on the lot facing Bowie Street (Figure 1). These were the first signs of a gradual deterioration in the fabric of the original neighborhood.

This was about the time when most of the children of the early families were marrying and moving out of the neighborhood. As the older generation passed away, the small adobe houses were rented to working-class people whose jobs were near enough to conveniently walk to work, saving the cost of transportation. One of the few exceptions was Christloeb Mueller's widow, who remained in her home at the corner of Dawson and Elm streets. 


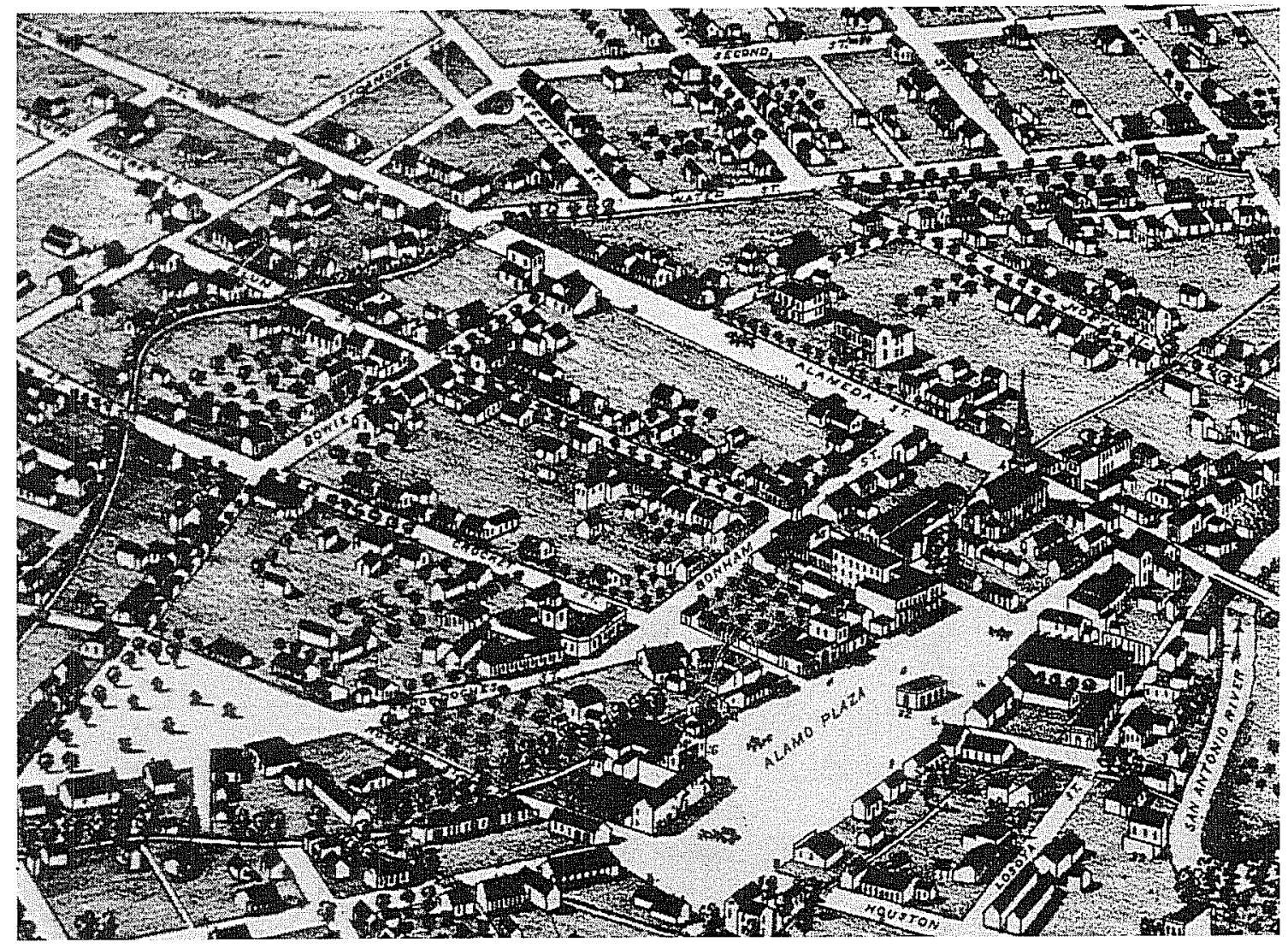

Figure 4. Detail of Augustus Koch's 1873 Bird's Eye View of the City of San Antonio. Facing south.

Her son, Chris, lived with her and worked as stage manager at the opera house on Alamo Plaza (CD 1901:401). Her daughter, Winnie, had married Robert Jenner, a local businessman, and they had built and moved into a house on the Mueller property, just north of her mother's house (CD 1901:316).

During the last part of the nineteenth century, several Victorian houses were built toward the northern part of the hotel property. One of these, on the lot facing onto Nacogdoches Street, was built by James Kampmann, a building contractor who also owned a large piece of property with an imposing home directly across Nacogdoches Street from the hotel site. One of these Victorian houses facing onto Elm Street at the north edge of the hotel property was owned by the Brackett family.

By 1905 the character of the neighborhood had almost completely changed (Table 1). The houses on the Bowie Street side of the hotel property were all rentals, with over half the tenants black. Only four of the residents owned their homes, two of them being members of the Mueller family and two widows-Proll and Brackett-of earlier residents.

No basic changes took place in the ethnicity of the residents of the block between 1905 and 1910, but as so often happens in rental neighborhoods, the names of the families all changed (Table 2). Elm Street was still home for the Mueller family. Mrs. Proll, on the southwest corner of Dawson and Elm streets, had taken in the Steimer family to share her house, and no doubt to help with the cost of maintaining it. The house on Nacogdoches Street had become a boarding house.

In the next four years the neighborhood's ethnic make-up changed (Table 3). This time, the predominance was toward Mexican-Americans, although few black residents remain. Again there had been a complete turnover, except for the widows Proll and Brackett and the Mueller family on Elm Street. The Nacogdoches Street boarding house continued under the same name and proprietors. Mr. Kempf had taken up the blacksmith shop where Jacob Vollmar was located in the late 1880 s. 
By 1921 (Table 4), the only families still remaining of the original owners were the widow Brackett and the recently widowed Minnie Mueller Jenner. The rest of the population was a mix of blacks and Mexican-Americans who held jobs such as waiters, porters, and maids.

The small adobe houses had stood up relatively well for 70 years, but were beginning to deteriorate by the 1920 s. It would not be long before they would become too expensive for absentee owners to adequately maintain. Most of the original owners had long since sold out to strangers who saw the property only as an investment opportunity.

The next major change in the area came with the city's widening of Elm Street in 1928. By acquiring a 13-ft strip of land along the east edge of all properties facing on the west side of the street (cf. BCDR 1037:25), they forced remodeling of the early adobes abutting the original street. By the late 1940s the properties facing onto Bowie Street had become primarily commercial enterprises, as the old adobe houses were removed to make way for the masonry block buildings that remain on the lots today.

\section{Summary}

The proposed site for a Hampton Inn in downtown San Antonio was first settled in the early 1850 s. Many of the small adobe houses built by German immigrants on the lots in the area continued in use for nearly 80 years before gradually giving way to modern commercial buildings.

The custom in the mid-nineteenth century of building the house directly on or very close to the street left large open areas in the rear for use by the residents. Some landowners built auxiliary buildings behind their houses, such as storage sheds, workshops, or privies (Figure 2). These were located along the sides or across the back of the lot, leaving the center of the lot open. Others later built a small house behind the original house for use by family members or to rent out for additional income.

Figure 2 shows the approximate location of the proposed hotel within the property to be developed, overlaid on the 1896 Sanborn Insurance Map (available on microfilm at the John Peace Library, The University of Texas at San Antonio). The Sanborn Map shows the maximum extent of construction on these lots during the development period. According to our best information, the hotel's footprint does not impact any major cultural features, such as houses or outbuildings, except for one small shed-like building.

Major concentrations of artifacts were not seen in the surface scatter. Additionally, examination of the test borings done by the firm of Raba-Kistner Consultants-indicated on Figure 2 as B-1, etc.reveals that the usual alluvial gray black clay loam encountered under downtown San Antonio sites is present within one foot of the surface over the area to be disturbed by hotel construction. Thus we know that the original yard surfaces, at least in this part of the site, have been altered by later commercial development and will probably not contain undisturbed information.

\section{Recommendations}

On the basis of our Phase I investigations, plus the fact that the rest of the hotel site is to be paved or minimally landscaped, we suggest that a minimum of archaeological testing will be required. The site of the small outbuilding should be tested and one or two $1-\mathrm{x}-1-\mathrm{m}$ units should be randomly located in the area to be excavated for the hotel.

We understand that it is the intention of Hampton Inns to uncover and use the acequia as a landscape feature. We would caution the contractor that the feature will require careful hand excavation. It is also important that the city of San Antonio be contacted to check on the present use or abandonment of the storm drain which fills the bottom of the acequia. Excavation of a section of 
this acequia directly south of the hotel site a number of years ago (Schuetz 1970) revealed exact details of its construction and the size and shape of the storm drain. This publication should be consulted before plans are made for restoration, and an archaeologist should monitor the excavation of the section of the acequia to be used in the landscaping scheme, or at least to advise the contractor on what he can expect to find.

Table 1. Residents on The Hampton Inn Property in 1905

\begin{tabular}{|c|c|c|c|}
\hline Location & Name & $\begin{array}{c}\text { Rent (R) or } \\
\text { Own (O) }\end{array}$ & Occupation \\
\hline \multicolumn{4}{|l|}{ Bowie Street } \\
\hline 408 & Annie Johnson & $\mathbf{R}$ & Washing \\
\hline 412 & Hattie Greenberry & $\mathbf{R}$ & No data \\
\hline 416 & Nellie McKinney & $\mathbf{R}$ & Washing \\
\hline 418 & Richard Nicholson & $\mathbf{R}$ & Porter, Karotkin Furniture \\
\hline 420 & J. C. Crawford & $\mathbf{R}$ & Carpenter \\
\hline 424 & John A. Lewis & $\mathbf{R}$ & Driver, Carter-Mullaly \\
\hline 426 & Frederick Laskow & $\mathbf{R}$ & Shoemaker \\
\hline \multicolumn{4}{|c|}{ Dawson Street } \\
\hline 101 & Miss Maria Bode & $\mathbf{R}$ & No data \\
\hline 102 & Jess H. Brown & $\mathbf{R}$ & Porter, Southern Pacific \\
\hline \multicolumn{4}{|l|}{ Elm Street } \\
\hline 131 & Mrs. M. Proll & 0 & Widow (Justus) \\
\hline 201 & Miss Mary Mueller & $\mathrm{O}$ & No data \\
\hline 205 & Robert C. Jenner & o & Jenner Manufacturing Co. \\
\hline 209 & A. S. C. West & $\mathbf{R}$ & Bookkeeper, Goggan \& Brothers \\
\hline 213 & Mrs. Ida Brackett & $\mathbf{O}$ & Widow (L. S.) \\
\hline \multicolumn{4}{|c|}{ Nacogdoches Street } \\
\hline 316 & Miss Jennie Walton & $\mathbf{R}$ & Dressmaker \\
\hline
\end{tabular}


Table 2. Residents on The Hampton Inn Property in 1910

\begin{tabular}{|c|c|c|c|}
\hline Location & Name & $\begin{array}{l}\text { Rent (R) or } \\
\text { Own (O) }\end{array}$ & Occupation \\
\hline \multicolumn{4}{|l|}{ Bowie Street } \\
\hline 408 & G. and Clara Herrera, Sr. & $\mathbf{R}$ & Works at Joske Bros. \\
\hline 412 & Claude and Paula Platt & $\mathrm{R}$ & No data \\
\hline 416 & Henry and Zula Malone & $\mathbf{R}$ & Waiter, Menger Hotel \\
\hline 418 & P. H. and Bertha Gaines & $\mathbf{R}$ & Minister \\
\hline 420 & Nellie Irvington & $\mathbf{R}$ & Rooms \\
\hline 424 & Martha White & $\mathbf{R}$ & Widow (Thomas) \\
\hline 426 & Charity Christian & $\mathrm{R}$ & Widow (Miles) \\
\hline \multicolumn{4}{|c|}{ Dawson Street } \\
\hline 101 & Henry and Marie Bailey & $\mathrm{R}$ & Porter, Angelus Bar \\
\hline 102 & William Tillman & $\mathbf{R}$ & No data \\
\hline \multicolumn{4}{|l|}{ Elm Street } \\
\hline \multirow[t]{3}{*}{131} & Mrs. M. Proll (H) & $\mathrm{O}$ & Widow (Justus) \\
\hline & J. and Ellen Steimel & & Work at Conness Realty \\
\hline & W. B. Steimer & & Clerk, Goggin \& Bro. \\
\hline 201, & Christ Mueller & O & No data \\
\hline 205 & Robert C. and Minnie Jenner & $\mathrm{O}$ & Jenner Manufacturing Co. \\
\hline 209 & Mrs. T. H. Hutchinson & $\mathbf{R}$ & Bookkeeper \\
\hline 213 & Mrs. Ida Brackett & 0 & Widow (L. S.) \\
\hline \multicolumn{4}{|c|}{ Nacogdoches Street } \\
\hline \multirow[t]{3}{*}{316} & The Orleans & & \\
\hline & Katie Schonstein & $\mathrm{R}$ & \\
\hline & Frank Schonstein & $\mathrm{R}$ & $\begin{array}{l}\text { Works at Braden-O'Neill } \\
\text { Plumbing }\end{array}$ \\
\hline
\end{tabular}


Table 3. Residents on The Hampton Inn Property in 1914

\begin{tabular}{|c|c|c|c|}
\hline Location & Name & $\begin{array}{c}\text { Rent (R) or } \\
\text { Own (O) }\end{array}$ & Occupation \\
\hline \multicolumn{4}{|l|}{ Bowie Street } \\
\hline 408 & R. Kempf & $\mathbf{R}$ & Blacksmith \\
\hline 412 & Theodora Garanza & $\mathbf{R}$ & No data \\
\hline 416 & Vicente and Sapopa Perez & $\mathbf{R}$ & Works at Carter-Mullaly \\
\hline 418 & Alice Howard & $\mathbf{R}$ & No data \\
\hline 420 & Louis and Petra Perez & $\mathbf{R}$ & No data \\
\hline 424 & T. and Mary Cruz & $\mathbf{R}$ & No data \\
\hline Rear & A. and Nellie Suniga & $\mathrm{R}$ & Works at Carter-Mullaly \\
\hline 426 & T. and Mary Cruz & $\mathbf{R}$ & Works at J. E. Mugge (grain dealer) \\
\hline \multicolumn{4}{|c|}{ Dawson Street } \\
\hline 101 & Carlos and Josepha Perez & $\mathbf{R}$ & Merchant \\
\hline 102 rear & W. D. and Lottie Jackson & $\mathbf{R}$ & Works at Menger Hotel \\
\hline \multicolumn{4}{|l|}{ Elm Street } \\
\hline 131 & Mrs. Margaret Proll & 0 & Widow (Justus) \\
\hline 201 & Mary Mueller & $\mathrm{O}$ & No data \\
\hline 205 & Robert C. and Minnie Jenner & $\mathrm{O}$ & Shipping clerk \\
\hline 209 & William and Lena Steinhardt & $\mathbf{R}$ & Pres., Hudson Auto Co. \\
\hline 213 & Mrs. Ida Brackett & 0 & Widow (L. S.) \\
\hline \multicolumn{4}{|c|}{ Nacogdoches Street } \\
\hline \multirow[t]{3}{*}{316} & The Orleans & & \\
\hline & Katie Schonstein & $\mathbf{R}$ & \\
\hline & Frank Schonstein & $\mathbf{R}$ & Bartender, Arthur Bar \\
\hline
\end{tabular}


Table 4. Residents on The Hampton Inn Property in 1921

\begin{tabular}{|c|c|c|c|}
\hline Location & Name & $\begin{array}{c}\text { Rent (R) or } \\
\text { Own (O) }\end{array}$ & Occupation \\
\hline \multicolumn{4}{|l|}{ Bowie Street } \\
\hline 408 & \multicolumn{3}{|l|}{ No listing } \\
\hline 412 & R. Kempf & $\mathbf{R}$ & Blacksmith shop \\
\hline 416 & J. and Nicolasa Riojas & $\mathbf{R}$ & Mail truck driver \\
\hline Rear & C. and Theresa Moody & $\mathbf{R}$ & Porter, Fischer Drug Store \\
\hline 418 & I. and Concha Abrejo & $\mathbf{R}$ & No data \\
\hline Rear & Andres and Refugio Garza & $\mathbf{R}$ & No data \\
\hline 420 & Mrs. Juanita Castro & $\mathrm{R}$ & Widow (Ben) \\
\hline Rear & Mauro and Librada Herrera & $\mathbf{R}$ & Waiter, Japanese restaurant \\
\hline 424 & S. and Concha Domingus & $\mathbf{R}$ & Machinist \\
\hline 426 & M. and Aurelia Ortega & $\mathbf{R}$ & Marble worker \\
\hline \multicolumn{4}{|c|}{ Dawson Street } \\
\hline 101 & S. and Minerva Fitzgerald & $\mathbf{R}$ & Porter, Victoria Hotel \\
\hline 102 & & & \\
\hline \multicolumn{4}{|l|}{ Elm Street } \\
\hline 131 & Mrs. Sophie Ozuna & $\mathbf{R}$ & Waitress \\
\hline 201 & S. and Amalia Ramirez & $\mathrm{R}$ & Shoemaker \\
\hline 205 & Mrs. Minnie Jenner & 0 & Widow (R. C.) \\
\hline 209 & Mrs. F. C. Bulgerin & $\mathbf{R}$ & Widow (H.) \\
\hline 213 & Mrs. Ida H. Brackett & 0 & Widow (L. S.) \\
\hline \multicolumn{4}{|c|}{ Nacogdoches Street } \\
\hline 316 & Mrs. Nora A. Klasing & $\mathbf{R}$ & Rooms \\
\hline
\end{tabular}




\section{Part 2. Backhoe Testing and Documentation of the Alamo Acequia}

\section{Anne A. Fox}

\section{Introduction}

The second phase of the Hampton Inn project was undertaken in April 1990. Anne A. Fox and Herbert G. Uecker, CAR archaeologists, conducted test excavations to locate the remains of the Alamo Acequia Madre where it crossed the proposed site for the new hotel. The purpose of the testing was to determine the condition, construction, and depth of the acequia. This information was subsequently used by Hampton Inns to complete landscaping plans for the hotel.

\section{Previous Work in the Area}

In December 1968, Mardith Schuetz of the Witte Museum uncovered a section of the acequia directly south of the proposed hotel property, this section remains open today. The acequia was found to average $4.5 \mathrm{ft}$ in width and to contain a concrete-covered storm drain which filled it to within approximately $1.5 \mathrm{ft}$ of the top course of stone lining. At that point, both walls of the acequia were intact, although the house to the east sat atop the east wall, using it for a foundation (Schuetz 1970:14-17).

In 1989 CAR conducted archival research to produce a history of the proposed hotel site for Hampton Inns (Part I). At this time, it was noted that a section of the Alamo Acequia Madre was located on the property.

\section{Current Test Excavations}

Five backhoe trenches, each two feet wide and approximately $20 \mathrm{ft}$ long, were dug in locations specified by Hampton Inn (Figure 1). Elevations above mean sea level (amsl) of selected points in the trenches are given in Table 5.The following observations were made during the testing.

Table 5. Elevation of Selected Points in Acequia Backhoe Trenches

\begin{tabular}{|c|c|c|c|c|}
\hline $\begin{array}{c}\text { Trench } \\
\text { Number }\end{array}$ & $\begin{array}{c}\text { Lowest Point } \\
\text { in Trench }\end{array}$ & $\begin{array}{c}\text { Top of West Wall } \\
\text { Of Acequia }\end{array}$ & $\begin{array}{c}\text { Top of East Wall } \\
\text { Of Acequia }\end{array}$ & $\begin{array}{c}\text { Top of Concrete } \\
\text { Storm Drain }\end{array}$ \\
\hline 1 & 657.06 & 658.73 & 658.33 & 659.34 \\
\hline 2 & 656.99 & & 659.16 & 658.13 \\
\hline 3 & 657.60 & & & \\
\hline 4 & 657.22 & & 658.54 & 658.16 \\
\hline 5 & 656.73 & 660.25 & 660.06 & 658.52 \\
\hline
\end{tabular}


Trench 1 was located just north of the Hampton. Inn property line. Both the east and the west walls of the acequia (Figure 5) were found about two feet beneath the present surface and were in relatively good condition, but perhaps missing the top course of stone. The concrete-covered storm drain was centered in the acequia, the top of it slightly lower than the tops of the acequia walls (Table 5).

Trench 2 was located approximately $65 \mathrm{ft}$ north of Trench 1. The east wall of the acequia was still intact and in good condition, but the installation of the concrete-covered drain pipe intruded approximately eight inches into the stone-robbed setting trench of the west acequia wall, indicating that the wall was removed before the laying of the pipe.

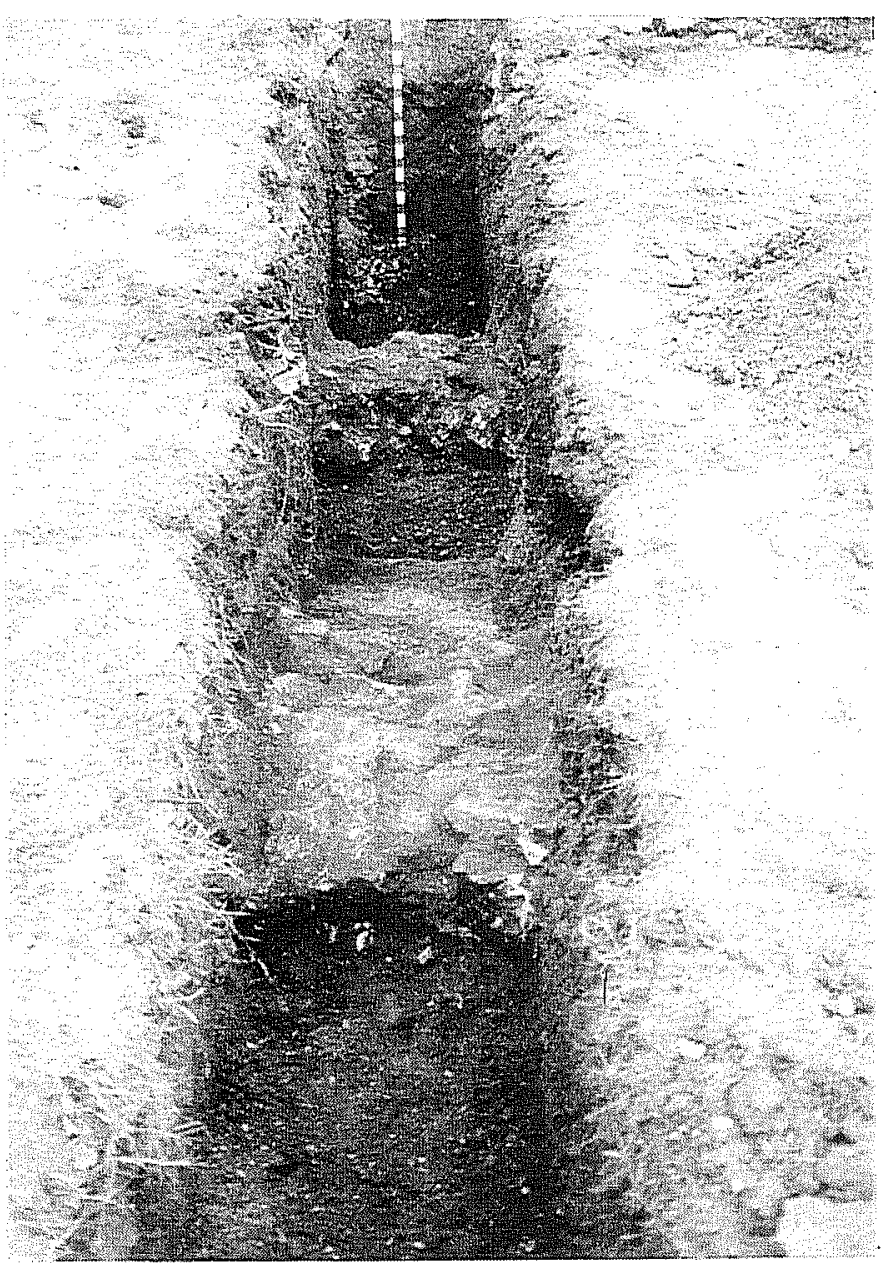

Figure 5. Trench 1, facing west. Both walls of the acequia are present in this trench.
Trench 3 was excavated about $55 \mathrm{ft}$ north of Trench 2. The entire depth of the trench encountered disturbance and demolition rubble, including a few cut stones, probably created during clearing of the surrounding lots and construction of the building. There was no trace of an acequia wall in place. A six-inch cast iron sewer line was found to run perpendicular to the back of the building a few feet north of the trench.

Trench 4 was located approximately $55 \mathrm{ft}$ north Trench 3. The east end of the trench encountered a considerable amount of demolition debris, including bricks, old newspaper, and a 1976 U.S. penny. Below this, however, the east acequia wall and drain pipe continued northward (Figure 6). There was no sign of the west acequia wall at this point.

Trench 5, ca. $10 \mathrm{ft}$ south of the chain-link fence marking the boundary of the Hampton Inn property, came right down on the east acequia wall. The concrete-covered pipe continued through the center of the acequia. A 20-inchwide cut stone foundation wall overlay the approximate location of the west acequia wall and cornered within the trench going west. Set into this wall was a vertical 3 -inch cast iron pipe at about the center of the test trench. Apparently this foundation is related to the construction of an outbuilding for the large one-and-one-halfstory house at 310 Bonham Street, which is no longer standing. A deep excavation into the sterile clay to the east of the east acequia wall revealed the bottom of the wall at an elevation of $656.73 \mathrm{ft}$ amsl.

\section{Conclusions And Recommendations}

Apparently the section of the acequia running through the Hampton Inn property has been considerably disturbed by installation of the storm drain and later construction and demolition activities in the area. It is also sufficiently deep below the present surface that it would be impractical to restore it for use in landscaping of the hotel grounds. We recom- 


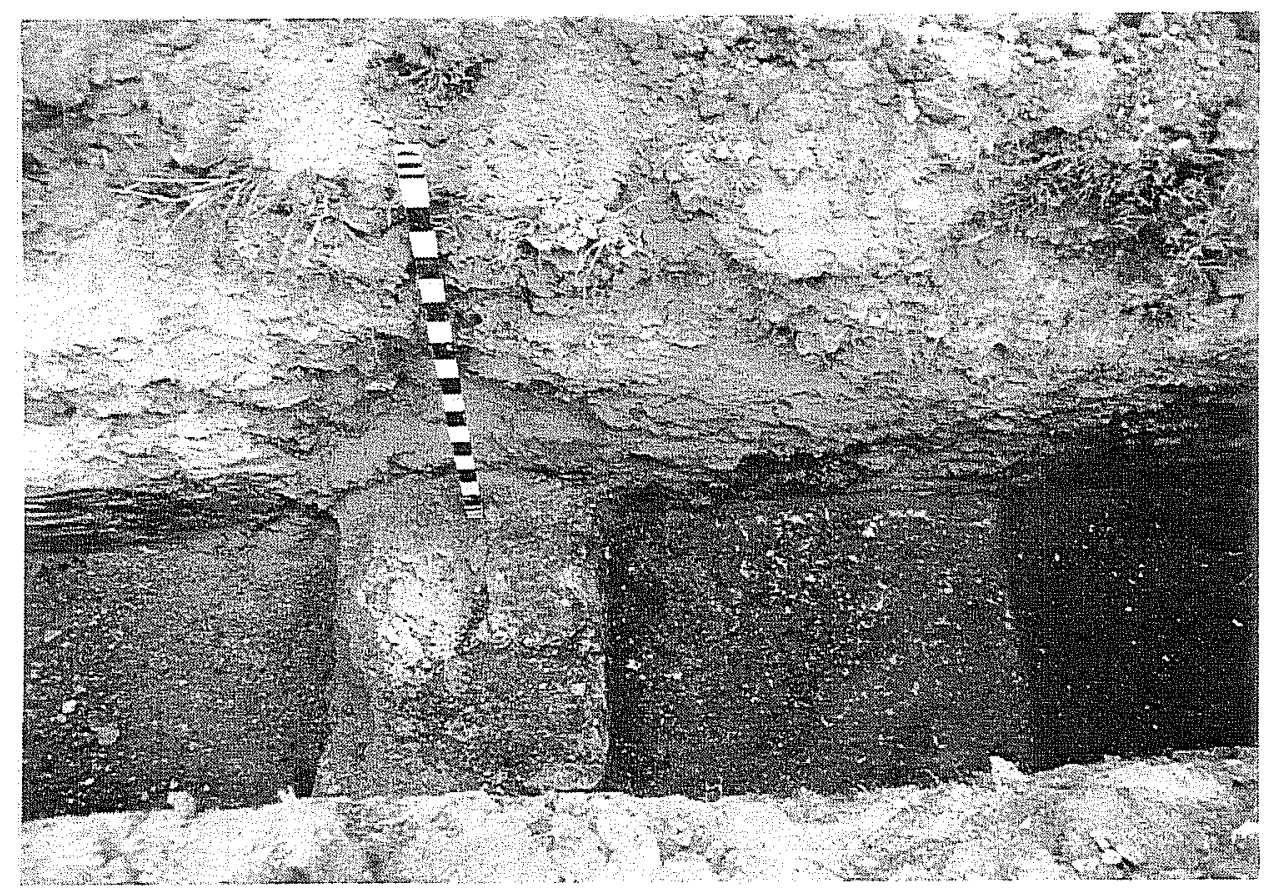

Figure 6. Trench 4, from above, showing the east wall of the acequia and the covered drain.

mend that consideration be given to the possibility of recreating the acequia directly above its historic location, using the open section to the south of the hotel property as a model for the proper stonework and proportions (see also Schuetz 1970 for details of construction). We do not under any circumstances recommend the removal of the present storm drain, as this would significantly damage what is left of the historic waterway. All decisions about redesign of the storm drain will have to be made in coordination with the utilities department, the historic preservation officer, and the City Historic Review Board. We cannot presently make recommendations on this aspect of the project.

At present, earthen fill over the top of the acequia walls averages one foot deep. In order to avoid damage by the weight of vehicles, we suggest that a concrete slab be laid over the sections of the acequia that will be used for driveway and parking. Care should be taken not to excavate deeply enough to encounter the tops of acequia walls.
There should be at least one foot of fill and gravel base between the tops of the walls and the bottom of the slab. The slab should project well outside the line of the acequia, overlapping two feet or more on each side. 


\section{Part 3. Final Monitoring During Construction}

\section{Waynne Cox and Anne A. Fox}

\section{Introduction}

The final phase of the Hampton Inn project involved monitoring of construction activities. In early 1995 the Office of Historical Preservation within the Planning Department of the city of San Antonio was informed that construction on the site had exposed nineteenth- and early twentiethcentury artifacts from near the acequia. A representative of the Office of Historical Preservation contacted on-site personnel and collected a number of items which were turned over to CAR for analysis. The Office of Historic Preservation strongly recommended that monitoring of construction be contracted before further excavation in the area be resumed.

\section{Monitoring}

CAR began monitoring in February 1995 with a visit to the construction site and coordination with Charles Johnson, construction supervisor. It was agreed that CAR archaeologists would make frequent visits during construction and that $\mathrm{CAR}$ would be notified prior to any further subsurface excavation. Frequent short visits to inspect progress on the site and to coordinate with the construction crew were make by CAR archaeologists I. Waynne Cox and Barbara A. Meissner.

In mid-June, an excavation for the porte-cochère exposed the foundation of the structure that had occupied the lot at 418 Bowie, NCB 554 (Figure 2). Photographic records were taken. On June 1 , an underground waste-water drainage line connection was begun in the vicinity of the path of the acequia and on-site monitoring was required. Excavation for the line began on Elm Street, near the northwest corner of the site, and progressed toward the west-southwest toward the northeast corner of the hotel structure. In the process, the southeast corner of the structure that had originally occupied 213 Elm Street, NBC 555, was exposed. Measurements and photographic records of the scant remains of the structure were recorded.

On June 16, excavations began for the swimming pool on the southwest side of the hotel and for the reconstruction of the acequia feature. The location and depth of the remaining stone of the acequia had been documented and carefully measured during the investigations in 1989 , and the reconstructed acequia had been engineered to be constructed to a depth that would not intrude upon the original structure. The excavation of the forming trench was carefully monitored and documented to insure that no damage to the buried resource would occur. Excavation progressed as planned and original stone was exposed in only two places along the route. The excavation for the swimming pool was accomplished without incident. The first 3 to $3.5 \mathrm{ft}$ was fill dirt from the hotel structure that had been distributed across the site; the remaining excavation, to a depth of seven feet in the deep end of the pool, encountered sterile black clay. All photographs and field notes are on file at CAR.

\section{Recovered Artifacts}

Sixteen historic artifacts were collected by the construction crew from near the acequia (Table 6). The artifacts were provided to CAR for analysis. These artifacts date to the late-nineteenth and early twentieth centuries. Due to the fact that we have no exact information about where they were found, there is not a great deal that can be inferred about 
them. The number of unbroken bottles suggests that they were recovered from some sort of trash deposit where they were protected, perhaps a well, a privy, or even the acequia.

When the foundation for the hotel was excavated, it was expected to cut through the site of a small structure in the backyard of 416 Bowie Street (Figure 2). Judging from experience at other sites in downtown San Antonio, we could confidently expect that this structure contained the family privy. This would have been abandoned and filled with household trash about 1900, when privies went out of use in this portion of the city. The Sanborn Insurance Maps for this area indicate that this structure disappeared between 1896 and 1904, which compares favorably with the dating of the artifacts.

\section{Summary}

Monitoring of construction activities at the Hampton Inn revealed small portions of the foundations of two structures, but no associated artifacts were discovered. Artifacts discovered by the construction crew in the back portion of the lot near the Alamo Acequia date to the nineteenth and twentieth centuries. The artifacts are at the hotel for a planned display on the site.

A reconstructed acequia was built along the original path of the acequia and represents approximately $100 \mathrm{ft}$ of a water-filled channel (Figures 7 and 8). The water is recirculated under a small bridge that leads to a neatly landscaped park-like environment to the rear of the hotel,

Table 6. Artifacts Collected in 1995

\begin{tabular}{|c|c|c|}
\hline Artifact & Color & Description/Notes \\
\hline Bottle & olive green & $\begin{array}{l}\text { square, } 73 / 4 \text { " high, relief molded letters, } \\
\text { "UDOLPHO WOLFE/AROMATIC SCHNAPPS/SCHIEDAM" }\end{array}$ \\
\hline Wine bottle & pale aqua & $113 / 4^{" ~ h i g h, ~ d e e p ~ k i c k u p ~}$ \\
\hline Flask & clear & blown in mold, 8 " high \\
\hline Medicine bottle & clear & corker, $47 / 8^{n}$ high \\
\hline Bluing bottles (2) & aqua & $\begin{array}{l}\text { corker, } 41 / 2 " \text { and } 7 " \text { high, relief molded letters, } \\
\text { "WYCKOFF \& COS/UNION/BLUING" }\end{array}$ \\
\hline Bottle & clear & screw top, 33/4 " high, possibly for shoe blacking \\
\hline Medicine bottle & clear & $\begin{array}{l}\text { screw top, } 31 / 2 \text { " high, relief molded measurements, } \\
\text { ".6. A47/U.S.A." on bottom }\end{array}$ \\
\hline Cosmetic jar & white & milk glass \\
\hline \multicolumn{3}{|l|}{ Slate pencil fragment } \\
\hline Token & & for trolley or local trade \\
\hline Axe head & & $7^{\prime \prime}$ long \\
\hline Automobile wrench & & $10^{\prime \prime}$ long, Model T \\
\hline Pistol & & double-barreled percussion, $7^{n}$ overall length \\
\hline Doubletree-clip & & iron wagon hardware \\
\hline Horseshoe & & \\
\hline
\end{tabular}


serving to illustrate the nature of the waterway when it was in use.

Hampton Inns, Inc., is to be commended for their concern for the history of San Antonio. The company's display of the artifacts and the reconstruction on the acequia serve as vivid reminders of the city's past and the importance of water to its residents.

Figures 7 and 8. Reconstructed acequia in the courtyard of the Hampton Inn, 1996.
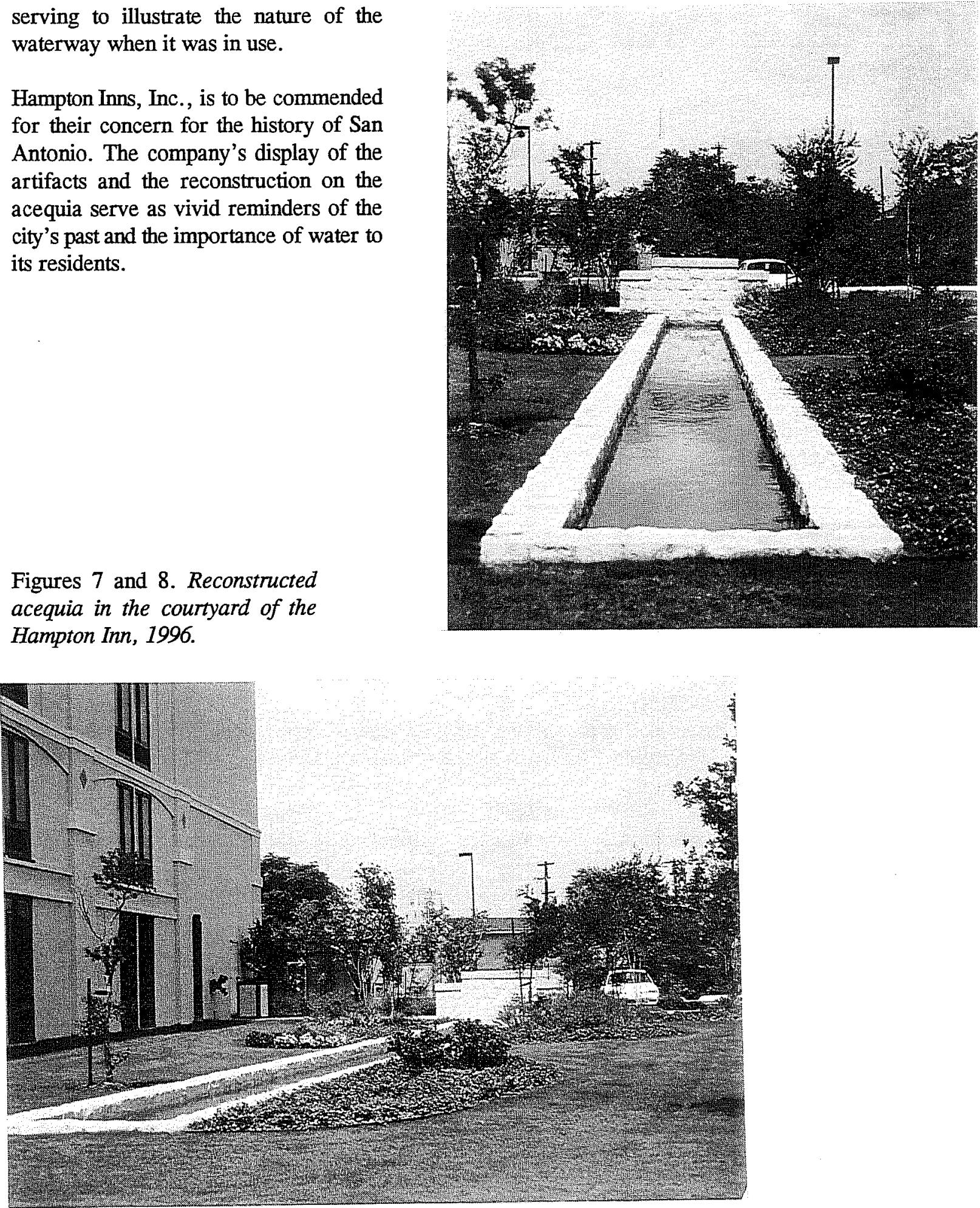


\section{References Cited}

Fox, A. A.

1977 The Archaeology and History of the Spanish Governor's Palace Park. Archaeological Survey Report, No. 31. Center for Archaeological Research, The University of Texas at San Antonio.

Fox, A. A., L. M. Flynn, and I. W. Cox

1987 Archaeological Studies for the San Antonio Channel Improvement Project, Including Investigations at Guenther's Upper Mill (41 BX 342). Archaeological Survey Report, No. 136. Center for Archaeological Research, The University of Texas at San Antonio.

Fox, A. A., and J. E. Ivey

1979 Historical Survey of the Lands Within the Alamo Plaza-River Linkage Development Project. Archaeological Survey Report, No. 77. Center for Archaeological Research, The University of Texas at San Antonio.

Fox, D. E.

1983 Traces of Texas History, Archeological Evidence of the Past 450 Years. Corona, San Antonio.

Fox, D. E., D. Scurlock, and J. W. Clark, Jr.

1977 Archeological Excavations at San Fernando Cathedral, San Antonio, Texas: A Preliminary Report. Special Report 22. Office of the State Archeologist, Austin.

Fox, D. E., F. Valdez, Jr., and L. O. Bobbitt

1978 An Archaeological Assessment of the Dolores Aldrete Property, San Antonio, Texas. Archaeological Survey Report, No. 55. Center for Archaeological Research, The University of Texas at San Antonio.

Habig, M. A.

1968 The Alamo Chain of Missions, A History of San Antonio's Five Old Missions. Franciscan Herald, Chicago.

Katz, P.

1978 Archaeological and Historical Investigations in the Arciniega Street Area, Downtown San Antonio, Texas. Archaeological Survey Report, No. 61. Center for Archaeological Research, The University of Texas at San Antonio.

Labadie, J. H.

1987 An Archaeological and Historical Assessment of the Vista Verde South Project, San Antonio, Texas. Archaeological Survey Report, No. 156. Center for Archaeological Research, The University of Texas at San Antonio.

McGraw, A. J.

1987 An Archaeological and Historical Program for Data Recovery along Houston and Bowie Streets, San Antonio, Texas. Manuscript on file. Texas State Department of Highways and Public Transportation, Highway Design Division, Austin. 
Schuetz, M. K.

1970 Excavation of a Section of the Acequia Madre in Bexar County, Texas and Archeological Investigations at Mission San Jose in April 1968. Archeological Report 19. Texas Historical Survey Committee, Austin. 
